\title{
PENGARUH PERFECTIONISM DAN DUKUNGAN SOSIAL TERHADAP PROKRASTINASI AKADEMIK DALAM MENYELESAIKAN TESIS DAN DISERTASI
}

\author{
Putri Anisahwati \\ Anggota HIMPSI DKI Jakarta \\ anisahwatiputri@yahoo.com
}

\begin{abstract}
This study aims to examine effects of perfectionism and social support on academic procrastination on graduate students at UIN Syarif Hidayatullah Jakarta in finishing thesis and dissertation. Multiple regression analysis used in this quantitative study with 112 graduate students as sample. Academic procrastination measurement tool used in this study was Likert scale questionnaire adapted by Syahputri (2013). Hewitt and Flett's Multidimensional Perfectionism scale and modified version of Cohen, Kamarck, and Hoberman's Interpersonal Support Evaluation List used in this study to measure independent variables. Result of this study showed that there are significant effect of perfectionism and social support on academic procrastination on graduate students at UIN Syarif Hidayatullah Jakarta in finishing thesis and dissertation with 25\% variance proportion. Based on minor hypothesis testing, four dimensions have significant influences, namely other-oriented perfectionism, tangible support, appraisal support, dan selfesteem support.
\end{abstract}

Keyword: perfectionism, social support, academic procrastination

\begin{abstract}
Abstrak
Penelitian ini bertujuan untuk mengetahui seberapa besar pengaruh perfectionism dan dukungan sosial terhadap prokrastinasi akademik pada mahasiswa Sekolah Pascasarjana UIN Syarif Hidayatullah Jakarta dalam menyelesaikan tesis dan disertasi. Penelitian kuantitatif dengan analisis regresi berganda ini menggunakan subjek penelitian sebanyak 112 mahasiswa Sekolah Pascasarjana UIN Syarif Hidayatullah Jakarta dari seluruh jumlah populasi sebanyak 1055 mahasiswa.

Alat ukur prokrastinasi akademik yang digunakan dalam penelitian ini adalah kuesioner model skala Likert yang diadaptasi dari Syahputri (2013). Alat ukur perfectionism yang digunakan adalah kuesioner model skala Likert yang dimodifikasi dari skala Multidimensional Perfectionism Scale (MPS) oleh Hewitt dan Flett (1991). Sedangkan alat ukur dukungan sosial yang digunakan adalah kuesioner skala Likert yang dimodifikasi dari alat ukur Interpersonal Support Evaluation List (ISEL) oleh Cohen, Kamarck, dan Hoberman (1985).

Hasil penelitian ini menunjukkan bahwa terdapat pengaruh yang signifikan antara perfectionism dan dukungan sosial terhadap prokrastinasi akademik pada mahasiswa Sekolah Pascasarjana UIN Syarif Hidayatullah Jakarta dalam menyelesaikan tesis dan disertasi dengan proporsi varians sebesar 25\%. Berdasarkan hasil uji hipotesis minor, diperoleh 4 dimensi yang memiliki pengaruh signifikan yaitu otheroriented perfectionism, tangible support, appraisal support, dan self-esteem support.
\end{abstract}

Kata kunci: prokrastinasi akademik, perfectionism, dukungan sosial.

\section{PENDAHULUAN}

Prokrastinasi merupakan masalah yang semakin umum tejadi di kalangan mahasiswa dalam beberapa tahun terakhir. Prokrastinasi dalam istilah psikologi dikenal sebagai perilaku menunda dalam mengerjakan atau menyelesaikan sesuatu. Hal ini 
menyebabkan seorang prokrastinator membuang-buang waktunya, meningkatkan kondisi stres dan menghasilkan prestasi akademik yang buruk.

Prokrastinasi akademik tidak hanya dialami oleh mahasiswa sarjana, tetapi juga dialami oleh mahasiswa pascasarjana dan merupakan masalah berat. Menurut Onwegbuzie (2004) mahasiswa pascasarjana cenderung sering menunda-nunda daripada mahasiswa sarjana. Berbeda dengan Özer (2011), menurutnya mahasiswa sarjana lebih menunda-nunda daripada pascasarjana.

Dari beberapa hasil penelitian ditemukan aspek-aspek pada diri individu yang berhubungan langsung dengan kecenderungan perilaku prokrastinasi salah satunya yaitu perfectionism. Beberapa penelitian menemukan hubungan yang signifikan antara perfectionism dengan prokrastinasi (Ferrari, 1992; Flett, Blankstein, Hewitt, \& Koledin, 1992; Frost et al, 1990). Johnson dan Slaney (dalam Yao, 2009) telah berhipotesis bahwa seseorang yang perfeksionis bisa lebih menunda karena kekhawatiran terhadap kemampuan mereka untuk menciptakan sesuatu yang sempurna. Hamacheck (dalam Yao, 2009) menambahkan bahwa hal tersebut dikarenakan seseorang dengan neurotic perfectionist sering menetapkan standar untuk diri mereka yang tidak mungkin dipenuhi dan mereka akan menghindari suatu kesalahan.

Perfectionism berhubungan dengan prokrastinasi yaitu karena tekanan dan tuntutan yang tinggi serta perasaan inferioritas menyebabkan perfectionism cenderung berusaha menghindari tugas tersebut. Tuckman (dalam Gunawinata, Nanik \& Lasmono, 2008) mengatakan bahwa seorang prokrastinator adalah pencari kesenangan dan berusaha menghindar dari hal-hal yang menekan mereka. Oleh karena itu, seorang yang perfeksionis dapat melakukan prokrastinasi sebagai coping terhadap tuntutan dan tekanan yang ia rasakan. Perfeksionis yang takut akan kegagalan dalam menyusun suatu karya ilmiah yang sempurna, akan berusaha menghindari dan menunda penyelesaiannya hingga detik-detik terakhir.

Adapun dimensi-dimensi perfectionism menurut Hewitt dan Flett (1991) ada tiga yaitu self-oriented perfectionism, other-oriented perfectionism dan socially-prescribed perfectionism. Dimensi pertama ialah self-oriented perfectionism kemungkinan memiliki pengaruh positif yang signifikan terhadap prokrastinasi akademik, karena menurut Flett dan Hewitt (2002) self-oriented perfectionism digambarkan sebagai seseorang yang memiliki standar yang tidak realistis untuk kinerja maupun perilaku dirinya sendiri. Sifat selforiented perfectionism ini seperti tidak ingin melihat kesalahan pada pekerjaannya serta memiliki motivasi yang kuat untuk menjadi sempurna.

Dalam proses menulis tugas akhir seperti tesis dan disertasi, seseorang dengan perfeksionis ini akan selalu berusaha mengumpulkan informasi dan referensi sebanyak mungkin untuk menghasilkan sebuah karya yang sempurna. Kemudian sang perfeksionis akan terus menunda mengerjakan tugasnya agar dapat menghasilkan karya yang sempurna tanpa cacat. Hal ini yang justru dapat menghambat proses penyelesaian menulis tesis atau disertasi dan mengakibatkan orang tersebut mengalami prokrastinasi.

Dimensi selanjutnya ialah other-oriented perfectionism, menurut Flett dan Hewitt (2002) Digambarkan sebagai seseorang yang menilai secara keras orang lain sesuai standar pribadinya yang tinggi dan standar tersebut terlalu sulit bagi orang lain. Seseorang dengan perfeksionis ini merasa tidak akan pernah puas menerima bantuan orang lain jika tidak sesuai dengan standarnya. Misalnya seperti meminta bantuan 
untuk menerjemahkan jurnal, mencarikan referensi, meminta masukan, atau meminta bantuan lain yang berkaitan dengan penyelesaian tesis dan disertasi. Jika hal tersebut tidak sesuai dengan standar yang ia tentukan, maka ia akan terus menerus mencari orang lain untuk diminta bantuan dan yang sesuai dengan standarnya. Secara tidak langsung, ini menyebabkan penyelesaian tesis dan disertasi menjadi terhambat dan dapat menyebabkan prokrastinasi.

Dimensi terakhir ialah socially-prescribed perfectionism yang kemungkinan memiliki hubungan positif dan signifikan terhadap prokrastinasi akademik. Menurut Flett dan Hewitt (2002) socially-prescribed perfectionism, yaitu seseorang yang mempunyai keyakinan atau anggapan bahwa orang di sekitarnya mempunyai standar yang tinggi terhadap perilaku dirinya dan mengharapkan dirinya menjadi sempurna. Digambarkan sebagai perasaan seseorang dimana dia merasa orang lain menilai dirinya dengan keras.

$\mathrm{Hal}$ ini mungkin dikarenakan mahasiswa dalam menyelesaikan tugas akhir seperti tesis dan disertasi dituntut untuk segera menyelesaikan tetapi karena proses pengerjaannya pasti menemui kesulitan, kesulitan itu yang menjadi penghambat dalam penyelesaian tesis dan disertasi yang akhirnya menyebabkan mahasiswa melakukan prokrastinasi.

Selain perfectionism, menurut peneliti dukungan sosial juga mempengaruhi prokrastinasi akademik. Pada penelitian sebelumnya dukungan sosial mempunyai pengaruh yang signifikan terhadap prokrastinasi akademik (Isnaini \& Istiana, 2008). Menurut Lawson dan Fuehrer (dalam Corneau, 2007) dukungan sosial merupakan moderator efektif stres yang dialami tahun pertama pada mahasiswa pascasarjana. Mereka menemukan bahwa jenis dukungan sosial yang diterima mahasiswa pascasarjana berbeda-beda tergantung pada kondisi dan situasi mereka.

Berdasarkan literatur dan fenomena yang telah peneliti paparkan di atas tersebut, maka peneliti merasa tertarik untuk mengkaji lebih dalam lagi dan mengetahui tentang "Pengaruh Perfectionism dan Dukungan Sosial terhadap Prokrastinasi Akademik dalam Menyelesaikan Tesis dan Disertasi"

\section{TEORI DAN HIPOTESIS}

Teori prokrastinasi pertama kali dikemukakan oleh Silver pada tahun 1974. Menurutnya prokrastinasi bukan hanya sebuah tindakan menghindari tugas, tetapi mungkin dalam kondisi tertentu menjadi keputusan yang sangat logis. Dia berpendapat bahwa orang yang menunda-nunda tidak berniat untuk mengabaikan atau menghindari tugas mereka untuk ditunda. Sebaliknya, mereka hanya menempatkan tugas yang harus dilakukan secara optimal sejenak melewati beberapa waktu untuk menjamin kemungkinan keberhasilan penyelesaian yang maksimal (Ferrari et al., 1995).

Berbeda dengan Ellis dan Knaus pada tahun 1975 (dalam Milgram, 1987) menurutnya prokrastinasi mengacu pada pola hidup yang panjang terhadap penundaan. Seperti menunda dalam mengambil keputusan besar dalam hidup, dan menyelesaikan tugas di menit terakhir dari komitmen yang telah ditetapkan.

Selanjutnya Burka dan Yuen (1985) mendefinisikan prokrastinasi adalah perilaku menunda pada tugas-tugas. Salomon dan Rothblum (1984) menambahkan 
prokrastinasi merupakan tindakan yang sia-sia yaitu menunda tugas sampai ke titik yang menyebabkan ketidaknyamanan subjektif. Kemudian Lay pada tahun 1986 (dalam Ferrari et al., 1995) mendefinisikan prokrastinasi sebagai kecenderungan irasional dalam menunda tugas yang harus diselesaikan.

Sedangkan menurut Milgram (1987) ada empat kriteria dari perilaku prokrastinasi, yaitu:

1. Inefficient behavioral process (proses dari perilaku yang tidak efisien, membuangbuang waktu)

2. Consequent substandard behavioral product (memiliki konsekuensi terhadap hasil dari pekerjaan).

3. Perceived legitimacy of task demand (dibatasi untuk tugas yang ingin dilakukan atau yang harus dilakukan).

4. Consequent emotional upset (menimbulkan emosi negatif, kesal dan kecewa dengan perilakunya).

Teori perfectionism menurut Burn (1980) didefinisikan sebagai orang yang memiliki standar di luar jangkauan atau di luar nalar dan yang bereaksi secara kompulsif secara terus menerus terhadap tujuan yang tidak mungkin. Bagi mereka hanya prestasi yang mengukur keberhasilan dan kebermaknaan. Dorongan utama mereka adalah menghindari kegagalan.

Sedangkan menurut Frost et al. (dalam Stöber, 1998) mengkonseptualkan Perfectionism menjadi enam dimensi: kekhawatiran yang berlebihan terhadap kesalahan (concern over mistakes), ragu-ragu dalam bertindak (doubts about actions), harapan orang tua (parental expectations), teratur (organization), kritikan (criticism), dan standar personal yang berlebihan tinggi (excessively high personal standards).

Kemudian Hewit dan Flett (dalam Ferrari et al., 1995) mendefinisikan Perfectionism adalah keinginan untuk mencapai kesempurnaan diikuti dengan standar yang tinggi untuk diri sendiri, standar yang tinggi untuk orang lain dan percaya bahwa orang lain memiliki pengharapan kesempurnaan untuk dirinya dan memotivasi.

Menurut Flett dan Hewitt (2002) ada tiga dimensi perfectionism, yaitu:

1. Self-orientated perfectionism, yaitu seseorang yang meletakkan standar tinggi untuk dirinya sendiri. Standar ini digunakan sebagai sebuah ukuran untuk mengevaluasi diri sendiri. Digambarkan sebagai seseorang yang memiliki standar yang tidak realistisk untuk kinerja maupun perilaku dirinya sendiri dan standar tersebut menjadi sebuah perintah yang keras bagi dirinya untuk mencapai keinginannya.

2. Other-orientated perfectionism, yaitu seseorang yang meletakkan standar dan harapan yang tinggi pada orang lain dan mengevaluasi perilaku dan cara kerja mereka berdasarkan standar tersebut. Digambarkan sebagai seseorang yang menilai secara keras orang lain sesuai standar pribadinya yang tinggi dan standar tersebut terlalu sulit bagi orang lain.

3. Socially-prescribed perfectionism, yaitu seseorang yang mempunyai keyakinan atau anggapan bahwa orang di sekitarnya mempunyai standar yang tinggi terhadap perilaku dirinya dan mengharapkan dirinya menjadi sempurna. Digambarkan sebagai perasaan seseorang dimana standar orang lain atas dirinya terhadap tingkah lakunya keterlaluan, dan merasa orang lain menilai dirinya dengan keras. 
Kemudian Blackler (2011) menyebutkan bahwa pada awal tahun 1990, Frost, Marten, Lahart, dan Rosenblate menyatakan bahwa terdapat enam dimensi perfectionism, yaitu:

1. Personal standards (standar personal); membangun standar yang tinggi untuk diri sendiri.

2. Organization (teratur); kecenderungan seseorang untuk menempatkan hal yang terpenting sebagai prioritas.

3. Parental Expectations (harapan orang tua); keyakinan bahwa orang tua memegang harapan yang begitu tinggi pada dirinya.

4. Parental Criticism (kritik orang tua); keyakinan bahwa orang tua terlalu memaksa dan kritis.

5. Doubts about action (ragu dalam berbuat); memiliki keraguan tentang kemampuan dirinya.

6. Concern about mistakes (khawatir berlebihan terhadap kesalahan); kecenderungan untuk khawatir secara berlebihan akan berbuat kesalahan dan keyakinan bahwa berbuat kesalahan berarti telah gagal.

Teori dukungan sosial menurut Caplan (dalam Sarason \& Sarason, 1985) ialah suatu sistem yang terdiri dari proses sosial secara terus menerus yang memberikan individu sebuah keuntungan melakukan timbal balik terhadap orang lain. Dukungan orang lain tersebut berupa memberikan informasi (information), bimbingan kognitif (cognitive guidance), sumber nyata (tangible resources), bantuan (aid); serta emosional yang didapat saat dibutuhkan.

Selanjutnya Cobb (1976) mengemukakan bahwa dukungan sosial ditandai sebagai informasi. Khususnya yang menginformasikan orang tersebut agar percaya bahwa ia diperhatikan, dicintai, dinilai, dihargai, termasuk jaringan komunikasi dan kewajiban bersama.

Kemudian House (dalam Sarason \& Sarason, 1985) menunjukkan bahwa "dukungan sosial adalah hubungan timbal balik antarpribadi yang melibatkan satu atau lebih dari hal-hal sebagai berikut: (1) menyangkut emosional (seperti perasaan disukai, dicinta, dan empati), (2) bantuan instrumental (seperti bantuan berupa barang atau jasa), (3) bantuan informasi (berkaitan tentang lingkungan), dan (4) bantuan appraisal (informasi yang relevan dengan evaluasi diri)".

Menurut Cohen, Kamarck dan Hoberman (dalam Sarason \& Sarason, 1985) menyimpulkan empat dukungan sosial, yaitu:

1. Tangible support, yaitu dukungan berupa bantuan material atau bantuan yang bersifat pelayanan, seperti membantu dalam melakukan kegiatan sehari-hari maupun bantuan secara finansial.

2. Appraisal support, yaitu dukungan yang berupa tersedianya seseorang untuk membicarakan masalah orang lain. Bentuk bantuan ini biasanya adalah membantu individu dalam memahami kejadian yang menekan dengan lebih baik serta memberikan pilihan strategi coping yang harus dilakukan guna menghadapi kejadian tersebut.

3. Self-esteem support, yaitu dukungan yang berupa tersedianya perbandingan positif ketika membandingkan diri sendiri dengan orang lain. Bentuk bantuan 
ini adalah individu merasakan adanya perasaan positif akan dirinya bila dibandingkan keadaan yang dimiliki dengan orang lain, yang membuat individu merasa sejajar dengan orang lain seusianya.

4. Belonging support, yaitu dukungan yang berupa tersedianya seseorang yang bisa melakukan hal bersama-sama. Bentuk bantuan ini adalah inidvidu tahu bahwa ada orang lain yang dapat diandalkan ketika ia ingin melakukan suatu kegiatan bersama.

\section{Hipotesis mayor}

$\mathrm{H}_{\mathrm{a}}$ : Tidak ada pengaruh perfectionism dan dukungan sosial terhadap prokrastinasi akademik dalam menyelesaikan tesis dan disertasi.

\section{Hipotesis minor:}

$\mathrm{H}_{1}$ : Ada pengaruh yang signifikan antara perfectionism dan dukungan sosial terhadap prokrastinasi akademik dalam menyelesaikan tesis dan disertasi.

$\mathrm{H}_{2}$ : Ada pengaruh self-oriented perfectionism pada variabel perfectionism terhadap prokrastinasi akademik dalam menyelesaikan tesis dan disertasi.

$\mathrm{H}_{3}$ : Ada pengaruh other-oriented perfectionism pada variabel perfectionism terhadap prokrastinasi akademik dalam menyelesaikan tesis dan disertasi.

$\mathrm{H}_{4}$ : Ada pengaruh social-prescribed perfectionism pada variabel perfectionism terhadap prokrastinasi akademik dalam menyelesaikan tesis dan disertasi.

$\mathrm{H}_{5}$ : Ada pengaruh tangible support pada variabel dukungan sosial terhadap prokrastinasi akademik dalam menyelesaikan tesis dan disertasi.

$\mathrm{H}_{6}$ : Ada pengaruh appraisal support pada variabel dukungan sosial terhadap prokrastinasi akademik dalam menyelesaikan tesis dan disertasi.

$\mathrm{H}_{7}$ : Ada pengaruh self-esteem support pada variabel dukungan sosial terhadap prokrastinasi akademik dalam menyelesaikan tesis dan disertasi.

$\mathrm{H}_{8}$ : Ada pengaruh belonging support pada variabel dukungan sosial terhadap prokrastinasi akademik dalam menyelesaikan tesis dan disertasi.

\section{METODE PENELITIAN}

Populasi dan sempel

Populasi penelitian yaitu mahasiswa program Magister (S2) dan Doktor (S3) tahun 2007-2013 yang masih proses penyelesaian tesis atau disertasi, meliputi:

1. mahasiswa tahun 2007-2010 yang telah mengikuti ujian alih status (rekualifikasi)

2. mahasiswa angkatan 2011-2013 yang telah mendapatkan pembimbing tesis atau promotor disertasi dan sedang menyelesaikan tesis dan disertasi

3. mahasiswa yang terkena denda ujian seperti ujian proposal tesis atau disertasi, WIP (Work in Progress), pendahuluan tesis atau disertasi.

Jumlah sempel yang digunakan dalam penelitian ini sebanyak 112 mahasiswa Sekolah Pascasarjana UIN Syarif Hidayatullah Jakarta.

\section{Variabel penelitian}

Variabel-variabel dalam penelitian ini adalah :

1. Dependent variable: Prokrastinasi akademik 
2. Independent variable: perfectionism (self-oriented perfectionism, other-oriented perfectionism, dan socially prescribed perfectionism) dan dukungan sosial (tangible support, appraisal support, self-esteem support, belonging support).

\section{Instrument pengumpulan data}

Dalam penelitian ini peneliti menggunakan tiga skala, yaitu:

1. Skala prokrastinasi akademik

Peneliti memodifikasi alat ukur yang dibuat oleh Syifa Alamiyah Syahputri dengan mengacu teori Milgram (1991) yang terdiri atas 35 berbentuk likert scale.

2. Skala perfectionism

Skala perfectionism peneliti ini menggunakan Multiple Perfectionism Scale (MPS) dari teori Flett dan Hewitt (1991) yang terdiri dari 45 item.

3. Skala dukungan sosial

Skala dukungan sosial dalam penelitian ini menggunakan Interpersonal Support Evaluation List (ISEL) dari teori Cohen (1985) yang terdiri dari 40 item.

\section{Uji validitas konstruk}

Untuk menguji keadaan instrumen yang digunakan pada penelitian ini, maka dilakukan uji validitas (lihat Tabel 1) dengan menggunakan CFA (Confirmatory Factor Analyis). Berdasarkan pada tabel 1 di bawah ini menunjukan bahwa hasil dari uji konstruk yang dilakukan dari tiga alat ukur yang digunakan dalam penelitian ini 6 item dinyatakan tidak valid $(\mathrm{t}<1,96)$ dan 74 item lainnya valid $(\mathrm{t}>1,96)$. 


\section{Tabel 1}

\section{Hasil ujian validitas konstruk}

\begin{tabular}{|c|c|c|c|c|}
\hline Instrumen & Dimensi & No. Item & $\begin{array}{c}\text { No. Item } \\
\text { tidak valid }\end{array}$ & $\begin{array}{c}\text { No. Item } \\
\text { yang valid }\end{array}$ \\
\hline $\begin{array}{l}\text { Prokrastinasi } \\
\text { akademik }\end{array}$ & $\begin{array}{l}\text { Inefficient behavioral } \\
\text { process } \\
\text { Consequent substandard } \\
\text { behavioral product } \\
\text { Perceived legiimacy of } \\
\text { task demands } \\
\text { Consequentd emotional } \\
\text { upset }\end{array}$ & $\begin{array}{l}1,2,3,4,5,6,7, \\
8,9,1011,12, \\
13,14 \\
15,16,17,18,19, \\
20 \\
21,22,23,29,30, \\
31 \\
24,25,26,27,28, \\
32,33,34,35\end{array}$ & $\begin{array}{l}1,2,8,13, \\
16\end{array}$ & $\begin{array}{l}3,4,5,6,7,9, \\
10,11,12,14, \\
15,17,18,19, \\
20,21,22,23, \\
24,25,26,27, \\
28,29,30,31, \\
32,33,34,35\end{array}$ \\
\hline Perfectionism & 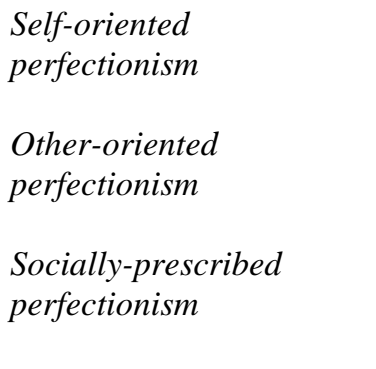 & $\begin{array}{l}1,6,8,12,14,15, \\
17,20,23,28,32, \\
34,36,42,40 \\
2,3,4,7,10,16, \\
22,26,19,24,27, \\
29,38,43,45 \\
5,9,11,13,18, \\
21,25,30,31,33, \\
35,37,39,41,44\end{array}$ & $\begin{array}{l}7,9,16, \\
21,22,26, \\
27,29,30, \\
34,37,38\end{array}$ & $\begin{array}{l}1,2,3,4,5,6, \\
8,10,11,12, \\
13,14,15,17, \\
18,19,20,23, \\
24,25,27,29, \\
30,31,32,33, \\
35,36,39,40, \\
41,42,43,44, \\
45\end{array}$ \\
\hline $\begin{array}{l}\text { Dukungan } \\
\text { Sosial }\end{array}$ & $\begin{array}{l}\text { Tangible support } \\
\text { Appraisal support } \\
\text { Self-esteem support } \\
\text { Belonging support }\end{array}$ & $\begin{array}{l}2,9,14,16,18, \\
23,29,33,35,39 \\
1,6,11,17,19, \\
22,26,30,36,38 \\
3,4,8,13,20,24, \\
28,32,37,40 \\
5,7,10,12,15, \\
21,25,27,31,34\end{array}$ & $\begin{array}{l}1,8,10, \\
16,18,23, \\
26,32,33, \\
34,37\end{array}$ & $\begin{array}{l}2,3,4,5,6,7, \\
9,11,12,13, \\
14,15,17,19, \\
20,21,22,24, \\
25,26,27,28, \\
29,30,31,35, \\
36,38,39,40\end{array}$ \\
\hline
\end{tabular}

\section{Metode analisis data}

Analisis data adalah proses penelaahan data agar dapat ditafsirkan untuk memberikan makna dan menjelaskan data yang diperoleh dan menjelaskan pola atau kategori, kemudian mencari hubungan antara berbagai konsep pengolahan data dilakukan dengan analisa data secara statistik sebagai cara untuk mengetahui pengaruh variabel bebas / independent variable yaitu self-oriented perfectionism, other-oriented perfectionism, socially prescribed perfectionism, tangible support, appraisal support, self-esteem support, dan belonging support terhadap variabel terikat / dependent variable yaitu prokrastinasi akademik.

Dalam rangka menjawab pertanyaan penelitian yaitu apakah terdapat pengaruh yang signifikan independen variabel terhadapdependen variabel, maka penulis menggunakan metode statistika, karena datanya berupa angka-angka yang merupakan hasil pengukuran atau perhitungan. Dalam hal ini hipotesis yang akan diukur, penulis menggunakan teknis analisis multiple regression atau analisis regresi berganda.

Hasil penelitian 
Tabel 2

Anova Pengaruh keseluruhan Independen Variabel terhadap Dependen Variabel

\begin{tabular}{llccccc}
\hline & & Sum of & & & & \\
& Model & Squares & Df & Mean Square & F & Sig. \\
\hline 1 & Regression & 2652,200 & 7 & 378,886 & 4,964 & $.000^{\text {a }}$ \\
& Residual & 7937,217 & 104 & 76,319 & & \\
& Total & 10589,417 & 111 & & & \\
& & & & & \\
\hline
\end{tabular}

a. Dependent Variable: prokrastinasi

b. Predictors: (Constant), belonging, sociallyprescribed, otheroriented, tangible, selforiented, selfesteem, appraisal

Berdasarkan data pada tabel 2 kolom ke 6 dari kiri diketahui bahwa $(\mathrm{p}<0.05)$ atau signifikan, maka hipotesis nol ditolak. Oleh karenanya hipotesis nihil yang menyatakan tidak pengaruh yang signifikan seluruh independent variable terhadap resiliensi ditolak. Artinya, ada pengaruh yang signifikan dari perfectionism (self-oriented perfectionism, otheroriented perfectionism, dan socially prescribed perfectionism), dukungan sosial (tangible support, appraisal support, selfesteem support, belonging support).

Langkah terakhir adalah melihat koefisien regresi tiap independent variable. Jika nilai $t>1,96$ maka koefisien regresi tersebut signifikan Hal ini menunjukkan bahwa bahwa independen variabel tersebut memiliki dampak yang signifikan terhadap resiliensi.

Tabel 3

Koefisien regresi

\begin{tabular}{llccccc}
\hline \multicolumn{1}{c}{ Model } & \multicolumn{2}{c}{ Unstandardized Coefficients } & $\begin{array}{c}\text { Standardized } \\
\text { Coefficient }\end{array}$ & T & Sig. \\
\hline & & B & Std.Error & Beta & & \\
\hline 1 & (Constant) & 28.493 & 17.873 & & 1.594 & .114 \\
& Self-oriented & .208 & .138 & .203 & 1.505 & .135 \\
& Other-oriented & .331 & .117 & .300 & 2.835 & .006 \\
& Socially- & -.055 & .150 & -.051 & -.365 & .716 \\
prescribed & .426 & .162 & .406 & 2.636 & .010 \\
Tangible & -.568 & .189 & -.538 & -2.997 & .003 \\
Appraisal & -.410 & .169 & -.375 & -2.423 & .017 \\
& Self-Esteem & .024 & .112 & .023 & .219 & .827 \\
\hline Belonging & & & & &
\end{tabular}

a. Dependent Variable: prokrastinasi

Berdasarkan koefisien regresi pada tabel 4.7 dapat disampaikan persamaan regresi sebagai berikut:

Prokrastinasi akademik $=28.493+0.208$ self-oriented +0.331 other-oriented -0.055 socially-prescribed +0.426 tangible support -0.568 appraisal support -0.410 self-esteem support +0.024 belonging support. 
Untuk melihat signifikan atau tidaknya koefisien regresi yang dihasilkan, kita cukup melihat nilai signifikan pada kolom yang paling kanan jika $\mathrm{P}<0.05$, maka koefisien regresi yang dihasilkan signifikan pengaruhnya terhadap prokrastinasi akademik dan sebaliknya. Dari hasil di atas, koefisien regresi dari other-oriented, tangible support, appraisal support dan self-esteem support dikatakan memiliki pengaruh yang signifikan sedangkan sisa lainnya tidak signifikan.

$\mathrm{Hal}$ ini berarti bahwa dari tujuh independent variable hanya tiga yang signifikan yaitu other-oriented, tangible support, appraisal support dan self-esteem support. Penjelasan dari nilai koefisien regresi yang diperoleh pada masing-masing independent variable adalah sebagai berikut:

1. Nilai koefisien regresi sebesar 0.208 pada variabel self-oriented perfectionism dengan signifikansi sebesar 0.135 (sig > 0.05). Hal ini menunjukkan bahwa self-oriented tidak memiliki pengaruh yang signifikan terhadap prokrastinasi akademik.

2. Nilai koefisien regresi sebesar 0.331 pada variabel other-oriented perfectionism dengan signifikansi sebesar 0.006 (sig < 0.05). Hal ini menunjukkan bahwa other-oriented perfectionism positif mempengaruhi prokrastinasi akademik secara signifikan. Artinya semakin tinggi other-oriented perfectionism maka semakin tinggi pula prokrastinasi, atau sebaliknya.

3. Nilai koefisien regresi sebesar -0.055 pada variabel socially-prescribed perfectionism dengan signifikansi sebesar 0.716 ( sig > 0.05). Hal ini menunjukkan bahwa sociallyprescribed perfectionism tidak memiliki pengaruh yang signifikan terhadap prokrastinasi akademik.

4. Nilai koefisien regresi sebesar 0.426 pada variabel tangible support dengan signifikansi sebesar 0.010 (sig < 0.05). Hal ini menunjukkan bahwa tangible support secara positif memiliki pengaruh yang signifikan terhadap prokrastinasi akademik. Artinya semakin tinggi dukungan berupa materi atau jasa yang diterima maka semakin tinggi pula prokrastinasi akademik.

5. Nilai koefisien regresi sebesar -0.568 pada variabel appraisal support dengan signifikansi sebesar $0.003($ sig < 0.05$)$. Hal ini menunjukkan bahwa appraisal support secara negatif memiliki pengaruh yang signifikan terhadap prokrastinasi akademik. Artinya semakin tinggi dukungan yang diterima berupa ketersediaan seseorang untuk menceritakan masalahnya maka semakin rendah prokrastinasi akademik.

6. Nilai koefisien regresi sebesar -0.410 pada variabel self-esteem support dengan signifikansi sebesar 0.017 (sig < 0.05). Hal ini menunjukkan bahwa self-esteem support memiliki pengaruh positif yang signifikan terhadap prokrastinasi akademik. Artinya semakin tinggi dukungan berupa penghargaan yang diterima seseorang maka semakin rendah prokrastinasi akademik, atau sebaliknya.

7. Nilai koefisien regresi sebesar 0.24 pada variabel belonging support dengan signifikansi sebesar 0.827 (sig > 0.05). Hal ini menunjukkan bahwa belonging support tidak memiliki pengaruh yang signifikan terhadap prokrastinasi akademik.

\section{Proporsi Varians}

Selanjutnya peneliti ingin mengetahui bagaimana penambahan proporsi varians setiap independent variabel terhadap prokrastinasi akademik. Pada tabel 4 kolom pertama adalah independent variable yang dianalis satu per satu, kolom kedua merupakan 
penambahan varians dependent variable dari tiap independent variable yang dimasukkan secara satu persatu tersebut.

Kolom ketiga merupakan nilai murni varians dependent variable dari tiap independent variable yang dimasukkan secara satu per satu, kolom keempat adalah nilai $\mathrm{F}$ hitung bagi independent variable yang bersangkutan. Kolom DF adalah derajat bebas bagi independent variable yang bersangkutan pula, yang terdiri dari numerator dan dunemerator yang telah ditentukan sebelumnya, nilai kolom inilah yang akan dibandingkan dengan nilai $\mathrm{F}$ hitung. Apabila $\mathrm{F}$ hitung lebih besar daripada $\mathrm{F}$ tabel, maka kolom selanjutnya, yaitu kolom signifikansi yang dituliskan signifikan dan sebaliknya.

\section{Tabel 4}

\section{Proporsi varians masing-masing independent variable}

1: SELFORIENTED, 2: OTHERORIENTED, 3: SOCIALPRESCRIBED, 4: TANGIBLE, 5:APPRAISAL, 6: SELFESTEEM, 7: BELONGING

\begin{tabular}{|c|c|c|c|c|c|c|c|c|c|}
\hline \multicolumn{10}{|c|}{ Model Summary } \\
\hline \multirow[b]{2}{*}{ Model } & \multirow[b]{2}{*}{$\mathrm{R}$} & \multirow{2}{*}{$\begin{array}{c}\mathrm{R} \\
\text { Square }\end{array}$} & \multirow{2}{*}{$\begin{array}{l}\text { Adjusted } \\
\text { R Square }\end{array}$} & \multirow{2}{*}{$\begin{array}{l}\text { Std. Error of } \\
\text { the Estimate }\end{array}$} & \multicolumn{5}{|c|}{ Change Statistics } \\
\hline & & & & & $\begin{array}{c}\text { R Square } \\
\text { Change }\end{array}$ & $\begin{array}{c}\mathrm{F} \\
\text { change }\end{array}$ & df1 & $\mathrm{df} 2$ & $\begin{array}{l}\text { Sig. F } \\
\text { change }\end{array}$ \\
\hline 1 & $.104^{a}$ & .011 & .002 & 9,75814 & .011 & 1.208 & 1 & 110 & .274 \\
\hline 2 & $.358^{\mathrm{b}}$ & .128 & .112 & 9,20235 & .117 & 14.689 & 1 & 109 & .000 \\
\hline 3 & $.359^{c}$ & .129 & .104 & 9,24379 & .001 & .025 & 1 & 108 & .875 \\
\hline 4 & $.419^{\mathrm{d}}$ & .175 & .145 & 9,03365 & .047 & 6.083 & 1 & 107 & .015 \\
\hline 5 & $.456^{\mathrm{e}}$ & .208 & .170 & 8,89702 & .032 & 4.312 & 1 & 106 & .040 \\
\hline 6 & $.500^{\mathrm{f}}$ & .250 & .207 & 8,69639 & .042 & 5.947 & 1 & 105 & .016 \\
\hline 7 & $.500^{\mathrm{g}}$ & .250 & .200 & 8,73610 & .000 & .048 & 1 & 104 & .827 \\
\hline
\end{tabular}

Keteran gan:

1. $\mathrm{X}_{1}$ : selforiented 2. $\mathrm{X}_{2}$ : Otheroriented 3. $\mathrm{X}_{3}$ : Sociallyprescrib ed

4. $\mathrm{X}_{4}$ : Tangible support

5. $\mathrm{X}_{5}$ : Appraisal support

6. $\mathrm{X}_{6}$ : Self-esteem support

7. $\mathrm{X}_{7}$ : Belonging support

Berdasarkan data pada tabel 4.8 dapat disampaikan informasi berikut:

1. Variabel perfectionism (self-oriented perfectionism) memberikan sumbangan varians sebesar $1.1 \%$ dari $25 \%$ pada prokrastinasi akademik. Sumbangan tersebut tidak signifikan karena $\mathrm{p}>0.05$ dilihat dari sig $\mathrm{F}$ change $=0.274$. Nilai $\mathrm{F}=1.208$ serta $\mathrm{df} 1=1$ dan $\mathrm{df} 2=110$.

2. Variabel perfectionism (other-oriented perfectionism) memberikan sumbangan varians sebesar $11.7 \%$ dari $25 \%$ pada prokrastinasi akademik. Sumbangan tersebut signifikan karena $\mathrm{p}<0.05$ dilihat dari sig $\mathrm{F}$ change $=0.000$. Nilai $\mathrm{F}=14.689$ serta $\mathrm{df} 1=1$ dan $\mathrm{df} 2=109$.

3 Variabel perfectionism (socially-prescribed perfectionism) memberikan sumbangan varians sebesar $0.1 \%$ dari $25 \%$ pada prokrastinasi akademik. Sumbangan tersebut tidak signifikan karena $\mathrm{p}>0.05$ dilihat dari sig $\mathrm{F}$ change $=0.875$. Nilai $\mathrm{F}=0.025$ serta $\mathrm{df} 1=1$ dan $\mathrm{df} 2=108$. 
4.. Variabel dukungan sosial (tangible support) memberikan sumbangan varians sebesar $4.7 \%$ dari $25 \%$ pada prokrastinasi akademik. Sumbangan tersebut signifikan karena $\mathrm{p}<0.05$ dilihat dari sig $\mathrm{F}$ change $=0.015$. Nilai $\mathrm{F}=6.083$ serta $\mathrm{df} 1=1$ dan $\mathrm{df} 2=107$.

5. Variabel dukungan sosial (appraisal support) memberikan sumbangan varians sebesar $3.2 \%$ dari $25 \%$ pada prokrastinasi akademik. Sumbangan tersebut signifikan karena $\mathrm{p}<0.05$ dilihat dari sig $\mathrm{F}$ change $=0.040$. Nilai $\mathrm{F}=4.312$ serta $\mathrm{df} 1=1$ dan $\mathrm{df} 2=106$.

6. Variabel dukungan sosial (self-esteem support) memberikan sumbangan varians sebesar $4.2 \%$ dari $25 \%$ pada prokrastinasi akademik. Sumbangan tersebut signifikan karena $\mathrm{p}<0.05$ dilihat dari sig $\mathrm{F}$ change $=0.016$. Nilai $\mathrm{F}=5.947$ serta $\mathrm{df} 1=1$ dan $\mathrm{df} 2=105$.

7. Variabel dukungan sosial (belonging support) memberikan sumbangan varians sebesar $0 \%$ dari $25 \%$ pada prokrastinasi akademik. Sumbangan tersebut tidak signifikan karena $\mathrm{p}>0.05$ dilihat dari sig $\mathrm{F}$ change $=0.827$. Nilai $\mathrm{F}=0.048$ serta $\mathrm{df} 1=1$ dan $\mathrm{df} 2=104$.

Dengan demikian dapat disimpulkan bahwa terdapat empat variabel independen, yaitu other-oriented perfectionism, tangible support, appraisal support, dan self-esteem support yang signifikan sumbangannya terhadap prokrastinasi akademik jika dilihat dari besarnya $\mathrm{R}^{2}$ yang dihasilkan dari sumbangan proporsi variabel yang diberikan.

\section{DISKUSI}

Berdasarkan hasil penelitian dan pengujian hipotesis, diketahui bahwa ada pengaruh yang signifikan dari variabel perfectionism (self-oriented perfectionism, other-oriented perfectionism dan socially-prescribed perfectionism) dan dukungan sosial (tangible support, appraisal support, self-esteem support dan belonging support) terhadap prokrastinasi akademik dalam menyelesaikan tesis dan disertasi dengan nilai koefisien regresi kurang dari 0.05.

Hal ini sesuai dengan beberapa penelitian terdahulu yang menemukan adanya hubungan yang signifikan antara perfectionism dengan prokrastinasi akademik (Ferrari, 1992; Flett, Blankstein, Hewitt, \& Koledin, 1992; Frost et al., 1990). Menurut Burka dan Yuen (dalam Ferrari et al., 1995) perfectionism merupakan kecenderungan untuk mendukung pentingnya keberhasilan secara terus-menerus dan menempatkan tuntutan yang tidak realistis pada diri mereka sendiri. Akibatnya seorang prokrastinator akan memiliki waktu tambahan untuk menyelesaikan tugas terbaiknya. Sehingga, ketika seseorang menyelesaikan tugas dengan standar yang tinggi dan tidak rasional, maka tugas-tugas tersebut tidak mungkin diselesaikan dengan tepat waktu (Ferrari et al., 1995).

Selanjutnya peneliti membahas empat dimensi dari tujuh dimensi yang memiliki pengaruh signifikan terhadap prokrastinasi akademik, yaitu other-oriented perfectionism, tangible support, appraisal suppor, dan self-esteem support. Dimensi other-oriented perfectionism pada perfeksionisme memiliki pengaruh positif terhadap prokrastinasi akademik.

Hasil penelitian ini sejalan dengan hasil penelitian Steel (dalam Gunawinata, Nanik, Lasmono, 2008) yang menemukan bahwa dari tiga dimensi prfectionism (selforiented perfectionism, other-oriented perfectionism dan socially-prescribed perfectionism) hanya 
other-oriented perfectionism yang berkaitan dengan prokrastinasi akademik meskipun korelasinya lemah. Hasil analisis data menunjukkan sebanyak 61 mahasiswa atau 55\% dikategorisasikan memiliki other-oriented perfectionism yang tinggi. Hal ini menunjukkan bahwa mahasiswa Sekolah Pascasarjana UIN Syarif Hidayatullah Jakarta cukup banyak yang memiliki kecenderungan other-oriented perfectionism dalam menyelesaikan tesis atau disertasi.

Menurut Flett dan Hewitt (2002) seseorang yang mempunyai keinginan kuat agar orang lain menjadi sempurna merupakan harapan yang sangat tidak realistis dan terusmenerus menjadi terlalu kritis terhadap orang di sekitar mereka. Harapan yang berlebihan tersebut dapat mengakibatkan kesulitan atau ketidakpuasan bagi orangorang yang dianalisis oleh seorang dengan other-oriented perfectionism. Misalkan mahasiswa dengan other-oriented perfectionism ini mengharapkan bantuan teman untuk mencarikan referensi rujukan, menerjemahkan literatur bahasa asing, mengajak teman untuk diskusi, atau meminta saran dan masukan mengenai tesis atau disertasi. Apabila semua itu tidak sesuai dengan harapan maka mahasiswa dengan other-oriented perfectionism ini akan dapat melakukan prokrastinasi dalam proses menyelesaikan tesis atau disertasi.

Hasil data selanjutnya menunjukkan bahwa dimensi yang signifikan berikutnya adalah dimensi tangible support. Menurut Cohen et al. (1985) bahwa tangible support ialah dukungan berupa bantuan material atau bantuan yang bersifat pelayanan, seperti membantu dalam melakukan kegiatan sehari-hari maupun bantuan secara finansial. Pada penelitian ini, skor kategorisasi tangible support mahasiswa dominan tinggi yaitu sebanyak 68 mahasiswa atau 61 \%. Ini berarti mahasiswa Sekolah Pascasarjana UIN Syarif Hidayatullah Jakarta mendapatkan tangible support yang baik.

Hasil penelitian ini sejalan dengan pendapat Cohen et al. (2000) bahwa tangible support dapat memecahkan masalah-masalah praktis, memungkinkan peningkatan waktu untuk istirahat dan relaksasi. Namun kenyataannya hasil menunjukkan bahwa tangible support signifikan terhadap prokrastinasi akademik namun arah hubungannya positif. Artinya dukungan yang diterima oleh mahasiswa justru membuat mereka menjadi prokrastinasi. Hal ini kemungkinan terjadi karena pernyataan alat ukur yang diadaptasi kurang menggambarkan dukungan nyata dalam penyelesaian studi yaitu tesis atau disertasi.

Dimensi selanjutnya yang signifikan adalah appraisal support. Menurut Cohen, et al. (2000) appraisal support dapat meningkatkan jumlah informasi berguna yang tersedia untuk individu. Selain itu, appraisal support juga dapat membantu mendapatkan layanan yang dibutuhkan. Jika dilihat dari skor kategorisasi, mahasiswa Sekolah Pascasarjana UIN Syarif Hidayatullah Jakarta yang memiliki appraisal support yang tinggi sebanyak 71 mahasiswa atau 63\%. Tingginya appraisal support menunjukkan bahwa mahasiswa menerima dukungan berupa ketersediaannya tempat untuk berbagi tekanan yang dirasa dan mendapatkan pilihan strategi coping untuk menghadapi masalahnya cukup banyak.

Menurut peneliti, ketika mahasiswa mengalami suatu kesulitan dalam menyelesaikan tesis atau disertasi maka dukungan seperti ini sangat membantu mahasiswa khususnya, ketika mahasiswa mengalami kesulitan dalam merevisi tesis atau disertasi setelah mengikuti serangkaian ujian. Di Sekolah Pascasarjana UIN Syarif 
Hidayatullah Jakarta misalnya setelah selesai mengikuti ujian WIP (work ini progress) mahasiswa akan langsung menemui teman atau sahabatnya untuk menceritakan pengalaman mereka selama proses ujian berlangsung. Kemudian mereka meminta bantuan, saran, serta masukan mengenai revisi yang mereka terima. Hal ini menunjukkan bahwa appraisal support sangat membantu mahasiswa untuk segera menyelesaikan revisi, sehingga membuat mahasiswa untuk tidak melakukan prokrastinasi.

Kemudian dimensi terakhir yang signifikan ialah self-esteem support. Menurut Cohen, et al. (2000) bentuk self-esteem support berupa pernyataan rasa cinta dan penerimaan diri individu dengan segala kesalahan dan kekurangan sehingga dapat menimbulkan kepercayaan diri seseorang juga bisa dalam bentuk penghargaan positif pada individu, pemberian semangat, persetujuan pada pendapat individu dan perbandingan yang positif dengan individu lain. Bentuk dukungan ini membantu individu dalam membangun harga diri dan kompetensi.

Menurut peneliti, ketika mahasiswa mengalami rasa putus asa dalam menyelesaikan tesis atau disertasi dengan menerima dukungan ini sangat penting. Karena saat mahasiswa merasa dirinya tidak percaya dengan dirinya dalam menyelesaikan tesis atau disertasi hal tersebut bisa mempengaruhi motivasinya. Apabila motivasi mulai berkurang maka penyelesaian tesis atau disertasi pun menjadi terhambat dan bisa menimbulkan perilaku prokrastinasi (Uyun, dalam Rumiani 2006).

Selanjutnya, dimensi-dimensi yang tidak signifikan terhadap prokrastinasi akademik dalam menyelesaikan tesis dan disertasi adalah dimensi self-oriented perfectionism, socially prescribed, dan belonging support. Dimensi pertama yang tidak memiliki pengaruh yang signifikan terhadap prokrastinasi akademik dalam menyelesaikan tesis dan disertasi ialah self-oriented perfectionism. Menurut peneliti, perilaku mahasiswa yang memiliki self-oriented perfectionism yang tinggi akan menjadikan seseorang memiliki standar yang sempurna terhadap tesis dan disertasi mereka, atau karena terlalu lama mencari bahan referensi yang terbaik sehingga menjadikan individu membuang waktu dan menimbulkan perilaku prokrastinasi. Namun pada penelitian ini self-oriented perfectionism hasilnya tidak signifikan terhadap prokrastinasi akademik. Hasil penelitian ini sama dengan hasil penelitian Hewitt dan Flett (1992).

Selanjutnya adalah dimensi socially-presscribe perfectionism. Dimensi ini tidak memiliki pengaruh yang signifikan terhadap prokrastinasi akademik dalam menyelesaikan tesis dan disertasi. Hasil penelitian ini sama dengan penelitian Indrayati Putri (2012) yang menyatakan bahwa tidak ada pengaruh yang signifikan antara socially-prescribed perfectionism dengan prokrastinasi akademik.

Dimensi terakhir adalah belonging support. Dalam penelitian ini dimensi belonging support juga tidak signifikan. Menurut Cohen, et al. (1985) belonging support adalah dukungan yang berupa tersedianya seseorang yang bisa melakukan hal bersama-sama. Bentuk bantuan ini adalah inidvidu tahu bahwa ada orang lain yang dapat diandalkan ketika ia ingin melakukan suatu kegiatan bersama.

Menurut peneliti, mahasiswa yang memiliki belonging support baik akan segera menyelesaikan studinya sesuai waktu yang ditentukan. Hal ini dikarenakan selama proses penyelesaian tesis dan disertasi individu akan sering melakukan diskusi 
penelitian, ke perpustakaan, dan melakukan kegiatan akademik lainnya secara bersama-sama dengan temannya. Namun kenyataannya penelitian ini menunjukkan bahwa tidak ada pengaruh yang signifikan antara belonging support dengan prokrastinasi akademik.

\section{Saran Praktis}

1. Insitusi

Pada penelitian ini ditemukan bahwa ada pengaruh perfeksionisme dan dukungan sosial terhadap prokrastinasi akademik dalam menyelesaikan tesis dan disertasi. Oleh karena itu, diharapkan kepada pihak Sekolah Pascasarjana UIN Syarif Hidayatullah Jakarta untuk membuka layanan psikologi bagi para mahasiswa untuk mengatasi perilaku prokrastinasi yang dialami mahasiswa dalam proses menulis tesis dan disertasi.

2. Mahasiswa

a. Mahasiswa diberikan pemahaman dan pembiasaan untuk menjauhi perilaku prokrastinasi, mengelola waktu dengan baik seperti membuat timetable, dan konsisten terhadap apa yang menjadi prioritas utamanya sebagai mahasiswa.

b. Hasil menunjukkan bahwa ada pengaruh yang signifikan dimensi other-oriented perfectionism terhadap prokrastinasi akademik. Dimensi tersebut mempunyai pengertian yaitu seseorang yang meletakkan standar tinggi untuk orang lain. Oleh karena itu, penulis memberikan saran untuk mahasiswa yang sedang dalam proses penyelesaian tesis atau disertasi supaya tidak menetapkan standar yang tinggi kepada orang lain. Seperti meminta bantuan dicarikan referensi yang benar-benar sesuai standar, menginginkan kritikan, masukan, dan saran yang sempurna, atau memita bantuan mentranslet referensi bahasa asing yang sesuai dengan EYD. Agar proses tersebut tidak menjadi penghambat dalam menyelesaikan tesis atau disertasi. 


\section{DAFTAR PUSTAKA}

Andarini, S.R \& Fatma, A. (2013). Hubungan antara distress dan dukungan sosial dengan prokrastinasi akademik pada mahasiswa dalam menyusun skripsi. Talenta Psikologi, II (2), 159-180.

Blackler,K. (2011). The efect of adaptive perfectionism, maladaptive perfectionism, and feedback on procrastination behavior. Thesis. Queen's University Kingston, Ontario, Canada.

Bungin, B. (2006). Metodologi penelitian kuantitatif: komunikasi, ekonomi, dan kebijakan publik serta ilmu-ilmu sosial lainnya. Jakarta: Kencana.

Burka, J. B., \& Yuen, L. M. (1985). Procrastination: Why you do it and what to do about it. Reading, PA: Addison-Wesley.

Burns, D. 0. (1980). Feeling good: the new mood therapy. New York: New American Library.

Burns, L., Dittmann, K., Nguyen, N., \& Mitchelson, J. (2000). Academic procrastination, perfectionism, and control: Associations with vigilant and avoidant coping. Journal of Social Behavior \& Personality, 15(5), 35-46.

Cao, L. (2012). Differences in procrastination and motivation between undergraduate and graduate students. Journal of the Scholarship of Teaching and Learning, 12 (2), 3964.

Cobb, J. (1976). Social Support as a moderator of life stress. Psychosomatic Medicine. 38, 300-314.

Cohen, S. Underwood, L.G. \& Gottlieb. B.H. (2000). Social support measurement and intervention: A guide for health and social scientists. New york: Oxford University Press.

Cohen S., Mermelstein R., Kamarck T., \& Hoberman, H.M. (1985). Measuring the functional components of social support. In Sarason, I.G. \& Sarason, B.R. (Eds), Social support: theory, research, and applications. The Hague, Netherlands: Martinus Niijhoff.

Corneau, K.Amy. (2007). Doctoral student social support and satisfaction with life. Disertation. The State University of New York.Buffalo.

Ferrari,J.R, Johnson,J., \& McCown,W.G.(1995). Procrastination and task avoidance theory and research. New York: Plenum Pers. 
Flett, G.R \& Hewitt, P.L. (2002). Perfectionism, theory, research and treatment, Washington: American Psychology Association.

Flett, Hewitt \& Koledin . (1992). Components of perfectionism and procrastination in college students. Social Behavior and Personality, 20(2), 85-94.

Gunawinata, V.A.R, Nanik \& Lasmono, H.K. (2008). Perfeksionisme, prokrastinasi akademik dan penyelesaian skripsi mahasiswa. ANIMA Indonesian Psychological Journal, 23. 256-276.

Hewitt, P. L., Flett, G. L., Donovan, W.T., \& Mikail, S. (1991). The multidimensional perfectionism scale: reliability, validity, and psychometric properties in psychiatric samples. Journal of consulting and clinical psychology, 3. 464-468.

Hewitt, P.L., \& Flett, G.L. (1990). Perfectionism and depression: A multidimensional analysis. Journal of Social Behavior and Personality 5, 423-438.

Indrayati, P. (2012). Pengaruh self-efficacy, perfeksionisme, dan faktor demografis terhadap prokrastinasi akademik pada mahasiswa fakultas psikologi UIN Syarif Hidayatullah Jakarta dalam menyelesaikan skripsi. Skripsi. Fakultas Psikologi UIN Syarif Hidayatullah Jakarta.

Jiao, Q. G., DaRos-Voseles, D. A., Collins, K. M. T., \& Onwuegbuzie, A. J. (2011). Academic procrastination and the performance of graduate-level cooperative groups in research methods courses. Journal of the Scholarship of Teaching and Learning, 11(1), 119-138.

Knaus, W. (2010). End procrastination now!. NewYork: McGraw Hill.

Milgram, N. (1987). The many faces of procrastination: implications and recomendation for concelors. Paper presented at the Anual International Council of Psychologits Convention (45th, New York, August 22-26, 1987), 23.

Mu'tadin, Z. (2002). Kesulitan menulis skripsi. http//www.e-psikologi.com/lainlain/zainun.htm. diakses 6 Oktober 2015.

Nurhayati, I. dan Kuswardani, I. (2008). Hubungan antara dukungan sosial keluarga dengan prokrastinasi akademik mahasiswa. Jurnal Psikohumanika I (2), 24-37.

Onwuegbuzie, A. (2004). Academic procrastination and statistics anxiety. Assessment \& Evaluation in Higher Education, 29(1), 3-19.

Onwuegbuzie, A., \& Jiao, Q. G. (2000). I'll go to the library tomorrow: the role of procrastination in library anxiety. College and Research Library, 61(1), 45-54.

Özer, B. U. (2011). A Cross Sectional Study on Procrastination: Who Procrastinate More? 2011 International Conference on Education, Research and Innovation, IPEDR, 18, 34-37. 
Özer, Demir, \& Ferrari. (2009). Exploring academic procrastination among turkish students: possible gender differences in prevalence and reasons. The Journal of Social Psychology, 149(2), 241-257.

Pardjono, Muhyadi, Nuchron, dan Widarto. (2013). Analisis faktor penghambat studi mahasiswa pascasarjana UNY. Laporan penelitian program Pascasarjana Universitas Negeri Yogyakarta.

Prasetyo, B. (2006). Metode penelitian kuantitatif: teori dan aplikasi. Jakarta: Raja Grafindo Persada.

Rumiani. (2006). Prokrastinasi akademik ditinjau dari motivasi berprestasi dan stres mahasiswa. Jurnal Psikologi Universitas Diponegoro 3 (2), 37-46.

Sarafino, E.P.; Smith T.W. (2011). Health psychology biopsychosocial interaction (7th edition). United states: john wiley \& sons, inc.

Sarason, I.G. \& Sarason, B.R. (1985). Social support: theory, research, and applications. The Hague, Netherlands: Martinus Nijhoff Publishers.

Senécal, C., Julien, E., \& Guay, F. (2003). Role conflict and academic procrastination: A selfdetermination perspective. European Journal of Social Psychology, 33, 135-145.

Solomon, L.J., and Rothblum, E.D. (1984). Academic procrastinastion: frequency and cognitive-behavioral correlates. Journal of Counseling Psychology, 31 (4), 503-509.

Steel, P. (2007). Nature of procrastination: a meta-analytic and theoritical review of quintessential self regulatory failure. Psychological Bulletin 133(1), 65-94.

Stöber, J. (1998). The Frost Multidimensional Perfectionism Scale: More perfect with four (instead of six) dimensions. Personality and Individual Differences, 24(4).

Stoeber,J., and Joormann,J. (2001). Worry, procrastination, and perfectionism: differentiating amount of worry, pathological worry, anxiety, and depression. Cognitive Therapy and Research, 25 (1), 49-60.

Syahputri, S. (2013). Pengaruh perfeksionisme, prokrastinasi dan jenis kelamin terhadap psychological distress mahasiswa yang sedang mengerjakan skripsi. Skripsi. Fakultas Psikologi UIN Syarif Hidayatullah Jakarta.

Taylor, S.E. (2009). Health Psychology (7th). NewYork: McGraw Hill

Tim Penyusun. Pedoman akademik program magister dan doktor tahun. 2009-2011. Sekolah Pascasarjana UIN Syarif Hidayatullah. Jakarta.

Yao, P.Melisa. (2009). An exploration of multidimensional perfectionism, academic self-efficacy, procrastination frequency, and asian american cultural values in asian American University Students. Dissertation. Ohio State University. 